\title{
SOLAR DESALINATION SYSTEM USING PARABOLIC COLLECTOR
}

\author{
Hendy, Z. "; M. M. Mostafa ; M. A. Elnono*; A. Lasheen ${ }^{* * *}$
}

\section{Z. S. Abdel-Rehim ****}

\section{ABSTRACT}

The aim of this study is to provide a modification unit to enhance the performance of the solar desalination. The modification of the conventional solar still by using the parabolic trough and simple heat exchanger which installed in the basin bottom as closed loop with the solar collector is presented in this work. Oil is used as working fluid in the heat exchanger which has high thermal properties. Black copper serpentine of the heat exchanger is immersed in basin water on the bottom of the still basin. It is extremely attached with thermally insulated pipelines through the trough. The oil is forced to flow using small pump. The parabolic trough is tracking the sun using simple mechanism to collect the highest amount of solar radiation and to increase the efficiency of the proposed solar desalination system. The saline water is heated directly by solar radiation and by the simple heat exchanger's hot oil. Many experiments are carried out on (September, October and November 2012). The experimental setup was designed and installed at Solar Energy Laboratory, Department of Agricultural Engineering, Faculty of Agriculture, Ain Shams University, Cairo $\left(\varphi=30^{\circ} \mathrm{N}\right)$. The forecast of the typical climatic conditions of the experimental Cairo site at the selected days are obtained from the Meteorological Egyptian Authority. The comparison between the performance of the conventional and the modified solar desalination still is presented. The economic study of the present system is determined. The results show that fresh water productivity is increased by an average of $41.07 \%$, while the total thermal efficiency of the modified system was $23 \%$ in the case of using modification still (active).

Keywords: Forced flow; oil heat exchanger; parabolic trough; solar still; solar desalination; solar tracking systems.

\footnotetext{
"Agric. Eng. Dept., Fac. of Agric., Ain Shams Univ.

*** Mech. Eng. Dept., Fac. of Eng., Banha. Univ.

**** Mech. Eng. Dept., National Research Center. Cairo.
} 


\section{1- INTRODUCTION}

7 he shortage of pure drinking water is an urgent problem that is continuously increased due to population growth, and changes in

1 weather conditions, and affected many developing countries in the world especially in remote areas. The Per capita water in Egypt is 700 $\left(\mathrm{m}^{3} /\right.$ inhabitant/year), (FAO). Therefore, with increasing water demand for agriculture and domestic usage with limited fresh water resources, the solar desalination seems to be the best solution for this problem. Egypt has a high potential for the production of solar energy that can be considered as a reliable energy source even during the winter season. The average solar energy has a magnitude of 5 to $8 \mathrm{kWh} / \mathrm{m}^{2}$ per day and sunshine duration per year extends to about 3000 hours Sayigh, (1977), Egypt also has long coastal areas (Red and Mediterranean seas).

There are different types of solar still systems can be found in the literature. Badran et.al., (2005) investigated a basin-type solar still and a flat plate collector that were connected together to study the effect of augmentation on still productivity. They found that the mass of distilled water using augmentation was increased by $52 \%$. Another experimental investigation was carried out by Elnono (2012) to study and test a singleslope solar still that was connected to a flat plat collector (active solar still) through a heat exchanger on the bottom of the still basin, and a small size pump to circulate the working fluid (distilled water) in a closed and separated loop from the basin water to transfer extra thermal energy to the solar still. He indicated that the average daily production rate of the active solar still was around 1.83 times higher than the passive solar still, while the thermal efficiency of the active solar still was lower than passive solar still by an average 3.9\%. A modification unit includes a solar parabolic trough (solar energy concentrator) with focal pipe and simple heat exchanger (serpentine) was developed by Abdel-Rehim and Lasheen, (2007). Oil was selected as working fluid. The oil was forced to flow using small pump which may be powered by PV system. The saline water is heated directly by solar radiation and also, by the oil in the heat exchanger as the oil cycle. The results showed that fresh water productivity was increased by an average of $18 \%$, due to the modification. 
An active solar desalination system should be characterized by the following:

1. Enhancement of solar desalination performance.

2. Using the solar energy sustainable as alternative and green energy.

3. Low cost of operation and maintenance.

4. High productivity of fresh water compared to other types.

5. Increasing the efficiency of solar desalination system under Egyptian condition all around the year.

\section{2- MATERIALS AND METHODS}

\subsection{Experimental work}

Two experimental set-ups are built; one of them was a passive solar still and the other was an active solar still under case study. The modification of the active solar still is done using the parabolic trough collector (solar concentrator) and simple heat exchanger, which installed on the basin bottom as closed loop with the solar collector.

Oil is selected as a working fluid, which has high thermal properties $(\rho$, $\mathrm{C}_{\mathrm{p}}$ and $\mathrm{K}$ ). The solar energy is used through the glass cover of the still and the parabolic trough system. Figures (1 and 2) show schematic diagram of the experimental set-up and photography picture, of the presented work, respectively, of the active and passive solar stills.

Figure (3) shows the flow diagram of the active system processes.

\section{1.1. Still basin}

Two solar stills are built for active and passive systems. They had the same size and dimentions. Each of them had L shape basin configuration, square cross sectional area of $1 \mathrm{~m}^{2}(1 \mathrm{~m} \times 1 \mathrm{~m})$ and made of galvanized iron sheet of $2 \mathrm{~mm}$ thickness. The basin water depth for the stills was $5 \mathrm{~cm}$. Saline water ( about 28608 ppm, 2.5 gm of sea salt per liter of tap water) is used as feed. They are oriented due North-South direction. Glass cover made of pure transparent material of $6 \mathrm{~mm}$ thickness is used as a condensing surface. The angle of inclination of the front glass cover is $30^{\circ}$ with the horizontal level to receive the highest amount of solar radiation. A rubber seal is placed between the glass inside by ordinary matt cover and the still, to prevent the thermal energy leakage to the 
surrounding. The external sides, bottom of the still and pipe lines are thermally insulated by $25 \mathrm{~mm}$ thickness glass wool to minimize the thermal losses to the ambient. The sides and bottom of the still are coated from black paint.

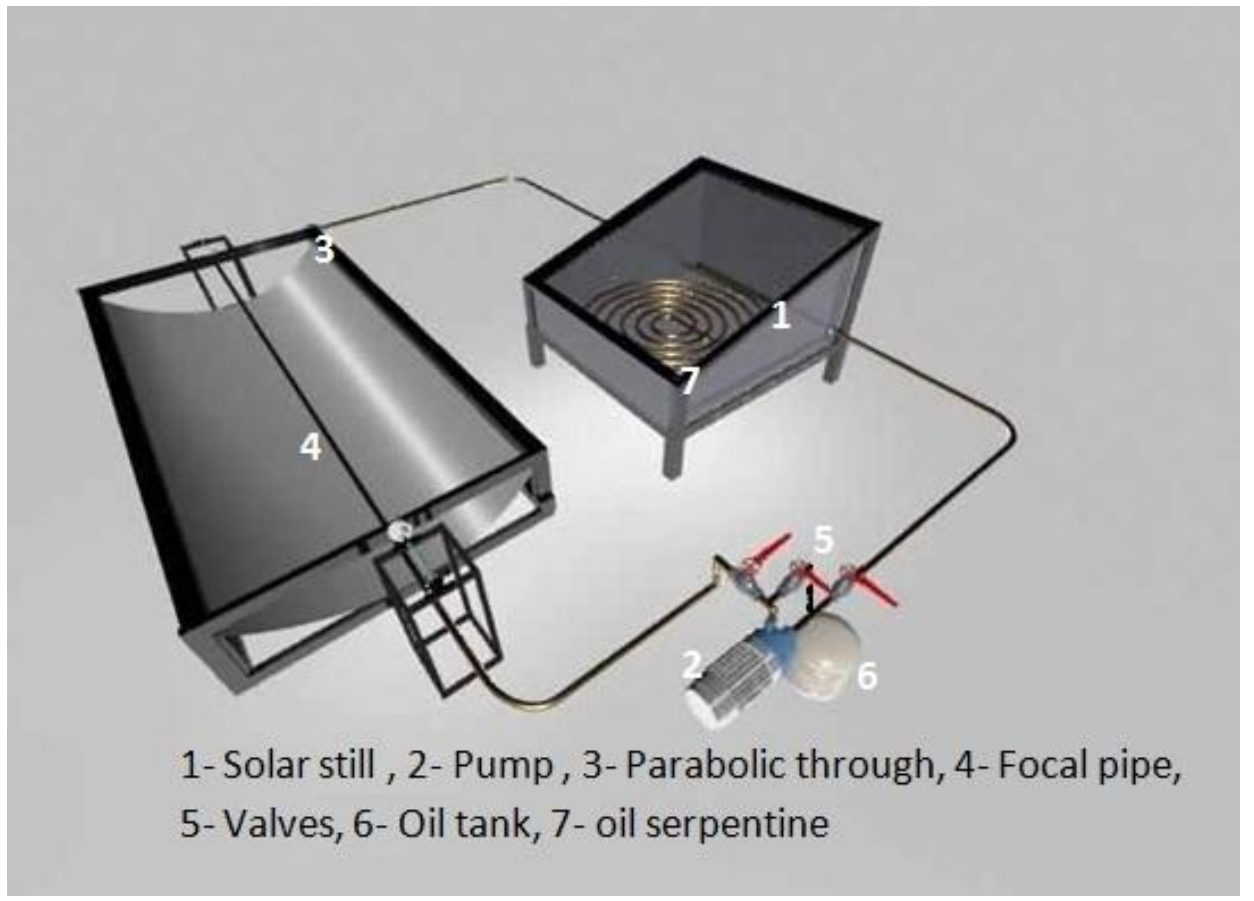

Fig. (1): Schematic diagram of experimental set-up of the modified

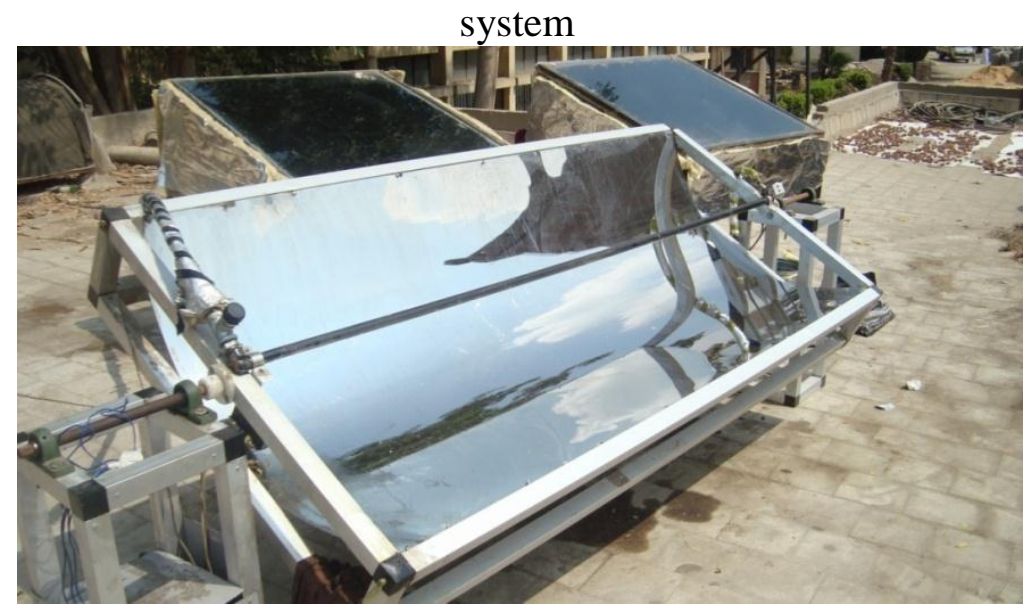

Fig • (2): Photography picture of the active and passive solar still 


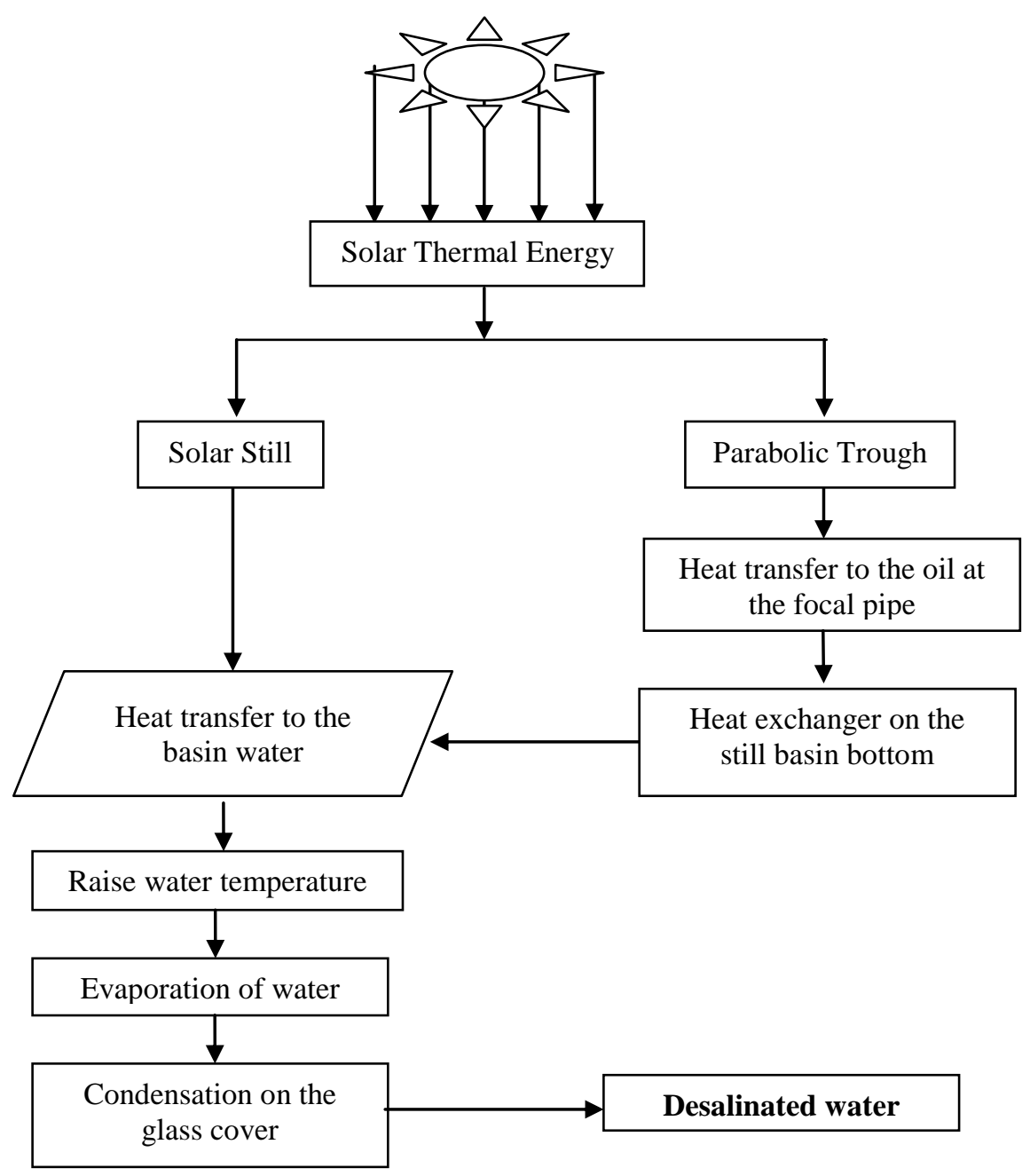

Fig. (3): Flow diagram of the active system processes

\subsubsection{Parabolic trough solar collector}

The Parabolic trough is solar concentrator, reflector and collector. It is manufactured from stainless steel sheet $1 \mathrm{~m} \times 2 \mathrm{~m}, 1.5 \mathrm{~mm}$ thickness and 2 $\mathrm{m}$ long. The pipe of $22 \mathrm{~mm}$ diameter is located at the focal line of the trough to collect the most of the reflected solar radiation. Figure (4) shows the incident on the surface of the trough and the reflected solar radiation on the focal pipe, that is painted by black color to absorb the highest amount of the solar energy. 


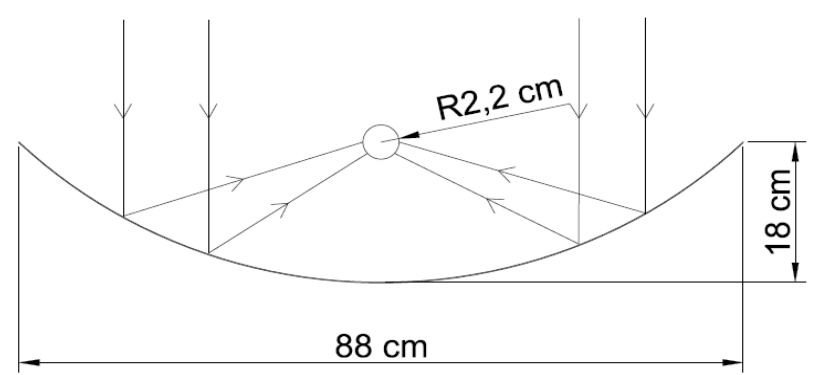

Fig. (4) : The incident on the surface of the trough and the reflected solar radiation on the focal pipe

For sun tracking a simple circut is used to follow the sun during the daylight hours. The sensors is used to search for maximum intensity till it reaches it to get the highest light solar intensity.

Two DC motors are used to control the movement of the parabolic trough. They recieved the signals from the light intensity circuit, that send two signals, one to turn the motor in the direction where the trough moves upward and the other to move downward by using two rollers and wire. Trough pipe is attached with serpentine loops (heat exchanger) of 8 mm inside diameter and 15 meters long, which lies on the bottom of the still basin in order to transfer extra thermal energy to the solar still. It is made of copper and is painted with matt black paint. Pump is used to circulate the oil through the pipeline loop in closed and separate loop from water basin as an average rate of $1.0 \mathrm{~L} / \mathrm{min}$ and about $50 \mathrm{Kpa}$ operating gage pressure to compensate the elevation between the pump and the collector, as well as the pressure drop due to the main and minor losses (Elnono, 2012). To insure pump self-priming and aviod air bleeding, it was advisable to use a small insulated vessel (5.0 Litter-size) with the pipe line that connect the external outlet connection of the heat exchanger with the intake mouth of the pump.The pump outlet was connected to the inlet connection of the prabolic trough collector by using two adjustment control valves as in Fig. (1) to adjust the discharge of an average $1.0 \mathrm{~L} / \mathrm{min}$ to flow to the collector and the rest of the pump discharge was by-passed to the insulated vessel. The required electrical 
energy for pump operation could be calculated ( by assuming the overall efficiency equal $75 \%$ and operating time equal $12 \mathrm{~h} /$ day) as the following:

$\begin{aligned} \text { the actual required power } & =\frac{P \times Q}{\eta_{\text {overall }}}=\frac{50 \times 1000 \times 1}{1000 \times 60 \times 75 \times 0.75} \\ =0.0015 \mathrm{hp} & =0.0015 \times 0.7457=0.0011 \mathrm{~kW}\end{aligned}$

the required electric energy $=0.0011 \times 12=0.0132 \mathrm{~kW} /$ day

LM35 Temperature Sensor is used for measuring temperature of the selected location inside the desalination system. The temperature sensor is connected with the digital temperature device, whose output voltage is linearly proportional to the Celsius temperature. It provides typical accuracies of $\pm 1 / 4^{\circ} \mathrm{C}$ at room temperature and $\pm 3 / 4^{\circ} \mathrm{C}$ over a full -55 to $+150^{\circ} \mathrm{C}$ temperature range.

The data acquisition system is developed. It is composed of a card system and a software program. The card converts the electric signal of the temperature sensors, and then to an electronic signal compatible with the computer. The software program converts the electronic signal to the temperature reading and saves the reading of all 13-temperature sensors every 15 minutes.

\subsubsection{Thermal Analysis of the Present Solar Desalination System}

At any given time the still produces an amount of distillate water equal to $\mathrm{Wp}(\mathrm{L} / \mathrm{m} 2)$ per unit area of the glass cover. Tw, Tg and To $\left({ }^{\circ} \mathrm{C}\right)$ are the average temperatures of basin water, the glass cover and ambient, respectively. The still receives solar radiation per unit area of $\mathrm{I}(\mathrm{W} / \mathrm{m} 2)$. The operation of solar desalination system is governed by the following heat balance equations. Fig. (5) shows the various components of energy balance and thermal energy loss in the active solar still (Abdel-Rehim and Lasheen, 2007). 


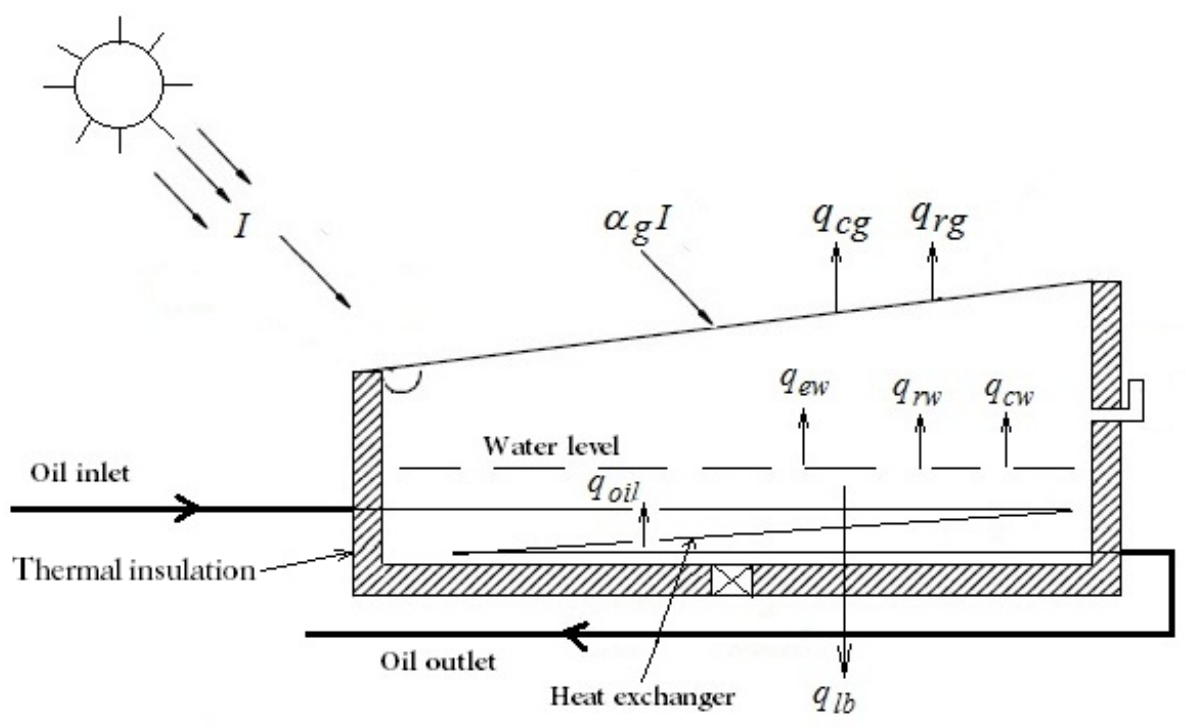

Fig. (5) : The various components of energy balance and thermal energy loss in the sactive solar still

\subsubsection{Solar energy equations of glass cover $\left(q_{g}\right)$ :}

The thermal energy balance equations of the glass cover are given as :

$$
\begin{aligned}
& q_{g}=\alpha_{g} I-q_{1 \mathrm{~g},, \mathrm{~W} / \mathrm{m}^{2}} \\
& q_{1 \mathrm{~g}}=q_{c g}+q_{r g}, \mathrm{~W} / \mathrm{m}^{2} \\
& q_{c g}=h_{c g}\left(T_{g}-T_{0}\right), \mathrm{W} / \mathrm{m}^{2} \\
& q_{r g}=\varepsilon_{g} \sigma\left[T_{g}^{4}-\left(T_{O}-11\right)^{4}\right], \mathrm{W} / \mathrm{m}^{2}
\end{aligned}
$$

Where:

$\mathrm{q}_{\mathrm{lg}}$ : The sum heat losses from the glass to the surrounding. $\mathrm{q}_{\mathrm{cg}}$ : The heat losses by convection.

$\mathrm{q}_{\mathrm{rg}}$ : Heat losses by radiation between glass cover to the surrounding. $\mathrm{h}_{\mathrm{cg}}$ : Heat transfer coefficient from the glass cover to the surrounding. $\varepsilon_{\mathrm{g}}$ : glass emissivity

б: Stefan Boltzman constant which equals $5.67 \times 10^{-8} \mathrm{~W} / \mathrm{m}^{2} \mathrm{~K}^{4}$

The rate of heat dissipation depends on the radiation to sky and on convection by air circulation. Radiation to sky depends on the effective 
sky temperature, which is generally taken as $11^{\circ} \mathrm{C}$, less than the ambient temperature.

$\mathrm{H}$ is the heat transfer coefficient from the glass cover to the surrounding and can be calculated as from (Duffie and Backman,1991):

$$
h_{c g}=5.7+3.8 W_{s}, \mathrm{~W} / \mathrm{m}^{2} \mathrm{~K}
$$

Where:

$\mathrm{W}_{\mathrm{s}}$ : wind speed $(\mathrm{km} / \mathrm{h})$

\subsubsection{Solar energy absorbed by basin water $\left(q_{w}\right)$ :}

The thermal energy equations of basin water are expressed as from (Rai,1980)

$$
q_{i w}=(\tau \alpha)_{w} I-q_{l w}, \mathrm{~W} / \mathrm{m}^{2}
$$

Where:

$(\tau \alpha) \mathrm{w}$ : the thermal transmissivity absorptivity of water, dimensionless and equals 0.816 .

$$
q_{i w}=q_{e w}+q_{r w}+q_{c w}+q_{H}+q_{o i l}+q_{l b}, \mathrm{~W} / \mathrm{m}^{2}
$$

Where:

$q_{i W}$ : is the input thermal energy to the basin water and can be obtained from the following equations:

(1) $q_{e w}$ : evaporated heat transfer rate at the saline water surface and is a function of the hourly distilled production of the fresh water $\left(W_{h}\right)$ and is calculated from the following relationship:

$$
q_{e w}=\frac{W_{p} \times 10^{-6} \times \rho_{w} \times L_{w}}{3600}, \mathrm{~W} / \mathrm{m}^{2}
$$

Where $\mathrm{L}_{\mathrm{w}}$ is the latent heat of water evaporation at the cover temperature and equals $2.35 \times 10^{6} \mathrm{~J} / \mathrm{kg}$.

(2) $\mathrm{q}_{\mathrm{rw}}$ is the heat transfer rate by radiation between the saline water and the inner glass cover surface and is given as:

$$
q_{r w}=\sigma F_{(w-g)}\left[\varepsilon_{w} T_{w}^{4}-\varepsilon_{g} T_{g}^{4}\right], \mathrm{W} / \mathrm{m}^{2}
$$


PROCESS ENGINEERING

Where:

$\varepsilon_{\mathrm{w}}$ and $\varepsilon_{\mathrm{g}}$ are water and glass absorptivity, dimensionless, and equal 0.96 and 0.89 , respectively

$\mathrm{F}_{(\mathrm{w}-\mathrm{g})}$ : the radiation shape factor from saline water to the inner glass surface and equals here 0.9 .

(3) $\mathrm{q}_{\mathrm{cw}}$ is the convective heat transfer rate $\left(\mathrm{W} / \mathrm{m}^{2}\right)$ between the saline water and the inner glass cover surface, it was given by Dunkle, (1961) as:

$q_{c w}=0.883\left[\left(T_{w}-T_{g}\right)+\left(\frac{P_{w}-P_{g}}{0.265-P_{w}}\right) \times\left(T_{w}+273\right)\right]^{1 / 3}\left(T_{w}-T_{g}\right)$

Where: $\mathrm{P}_{\mathrm{w}}$ and $\mathrm{P}_{\mathrm{g}},\left(\mathrm{MN} / \mathrm{m}^{2}\right)$, are the partial pressure of water at $\mathrm{T}_{\mathrm{w}}$ and $\mathrm{T}_{\mathrm{g}}\left({ }^{\circ} \mathrm{C}\right)$ respectively.

(4) $q_{o i l}$ is the rate of heat transfer from the oil to water which is energy absorbed by oil (serpentine) and transferred to the basin water due to the heat exchange between them.

$$
\begin{aligned}
& q_{\text {oil }}=\left[m \times c_{p} \times\left(T_{\text {in }}-T_{\text {out }}\right)\right]_{\text {oil }} \text { ? } \\
& =\left[U \times A \times\left(T_{\text {in }}-T_{\text {out }}\right)\right]_{\text {oil }} \quad\left(\mathrm{W} / \mathrm{m}^{2}\right)
\end{aligned}
$$

Where: $\mathrm{U}$ is the overall heat transfer coefficient, $\mathrm{W} / \mathrm{m}^{2}{ }^{\circ} \mathrm{C}$.

Then, the overall heat transfer coefficient can be calculated as:

$$
\boldsymbol{U}=\frac{\boldsymbol{q}}{\boldsymbol{A} \Delta \boldsymbol{T}_{\text {in }}} \quad \mathrm{W} / \mathrm{m}^{2} \mathrm{~K}
$$

(5) $\mathrm{q}_{\mathrm{Lb}}$ is the heat losses from the basin base to the ground. It can be calculated as:

$$
q_{l b}=h_{l b}\left(T_{w}-T_{o}\right), \mathrm{W} / \mathrm{m}^{2}
$$

Where: $h_{L b}$ is the convective heat transfer coefficient of the basin base and its function of thermal conductivity and the thickness of the insulation material which can be calculated as follows:

$$
h_{l b}=\frac{K_{m}}{X_{m}}, \mathrm{~W} / \mathrm{m}^{2}
$$

Where: $K_{m}$ and $X_{m}$ are the thermal conductivity and thickness of the thermal insulation and equal $0.04 \mathrm{~W} / \mathrm{m}^{\circ} \mathrm{C}$ and $0.5 \mathrm{~m}$, respectively. 


\subsubsection{Operational Efficiency of Solar Still}

The expression for operational thermal efficiency of the solar still may be written as (Elnono,2012)

a) Passive solar still

1. The hourly thermal efficiency

$$
\eta_{\text {passive, }}=\frac{\left(m \times 10^{-3}\right) \rho_{w} L_{w}}{A_{s} I_{s}(t) \times 3600}
$$

2. The daily thermal efficiency

$$
\eta_{\text {passive,d }}=\frac{\sum\left(m \times 10^{-3}\right) \rho_{w} L_{w}}{A_{s} \sum I_{s}(t) \times 3600}
$$

b) Active solar still obtained as the following:

1. The hourly thermal efficiency

$$
\eta_{\text {active, }}=\frac{\left(m \times 10^{-3}\right) \rho_{w} L_{w}}{A_{s} I_{s}(t) \times 3600+A_{a} I \times 3600}
$$

2. The daily thermal efficiency

$$
\eta_{\text {active, }}=\frac{\sum\left(m \times 10^{-3}\right) \rho_{w} L_{w}}{A_{s} \times \sum I_{s}(t) \times 3600+A_{a} \times \sum I \times 3600}
$$

Where:

$\mathrm{m}$ : the hourly productivity, $(\mathrm{ml} / \mathrm{h})$.

$\mathrm{A}_{\mathrm{s}}$ : the area of the solar still, $\left(\mathrm{m}^{2}\right)$.

$\mathrm{A}_{\mathrm{c}}$ : the area of the solar collector, $\left(\mathrm{m}^{2}\right)$.

$I_{s}(t)$ : the solar flux on the inclined glass cover of the solar still, $\left(\mathrm{W} / \mathrm{m}^{2}\right)$.

$\rho_{\mathrm{w}}$ : the density of water ( assumed to be $1000 \mathrm{~kg} / \mathrm{m}^{3}$ ).

Aa: collector aperture area, $\left(\mathrm{m}^{2}\right)$.

$\mathrm{L}_{\mathrm{w}}$ : the latent heat of water evaporation at the saturation temperature $\mathrm{T}_{\mathrm{w}}$ (assumed to be $2.35 \times 10^{3} \mathrm{KJ} / \mathrm{kg}$ ).

\section{3- RESULTS AND DISCUSSION}

Various experiments were carried out and the average measurements of temperature, relative humidity, wind speed, solar intensity and distilled water production were taken on hourly basis for several days of three months (September, October and November, 2012) for the active and the passive solar still during the daylight hours (from 7:00 AM. to 6:00 PM). All temperature variation, fresh water productivity and accumulated fresh water per day for the active and the passive solar desalination systems 
under case study are presented and illustrated in Figs.(6-11) for different months.

\subsection{Hourly Variations of Temperature}

\subsubsection{Hourly variations of ambient and inner glass temperature}

The hourly variation of the ambient, $T_{a}$, and inner glass cover temperatures, $T_{g \mathrm{i}}$ and $\mathrm{T}_{\mathrm{go}}$ for active and passive still is illustrated in Fig. (6). The temperature of the inner glass cover is higher than the outlet glass temperature and have peak values around the noon interval (12:00 4:30) for active and passive still. The maximum temperature for the active solar still for the inner and outer glass temperature were This is due to the release of more heat of condensation on the inner surface of glass cover, although the temperature values of the active solar still are higher than the passive solar still.

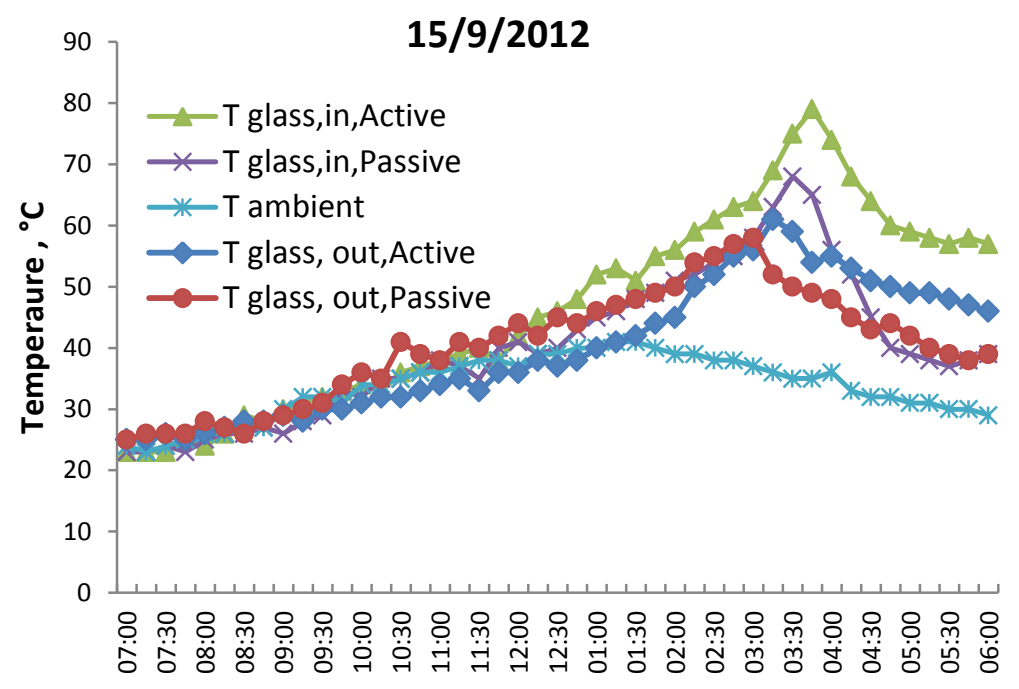

Day time, hour

Fig. (6). Variations of ambient temperature and inner glass temperature for the passive and the active solar stills (15/9/2012)

\subsubsection{Hourly variations of ambient and basin water temperature}

Figure (7) shows the hourly variation of basin water temperatures, $T_{w}$, and ambient temperature, $T_{a}$. It is obvious that all temperatures increase and begin decrease after 4:00 PM with respect to the variation of the solar radiation and due to transfer extra thermal energy to the basin water 
of the active solar still from the parabolic trough collector through the heat exchanger, although the temperature values of the active solar still are higher than the passive solar still. The average basin water temperature of the active solar still reached the highest value about $90 \mathrm{C}^{\circ}$ during the

period from 3:00 until 4:00 p.m. on Sep. 15, 2012, while it was $6490 \mathrm{C}^{\circ}$ for the passive solar sill.

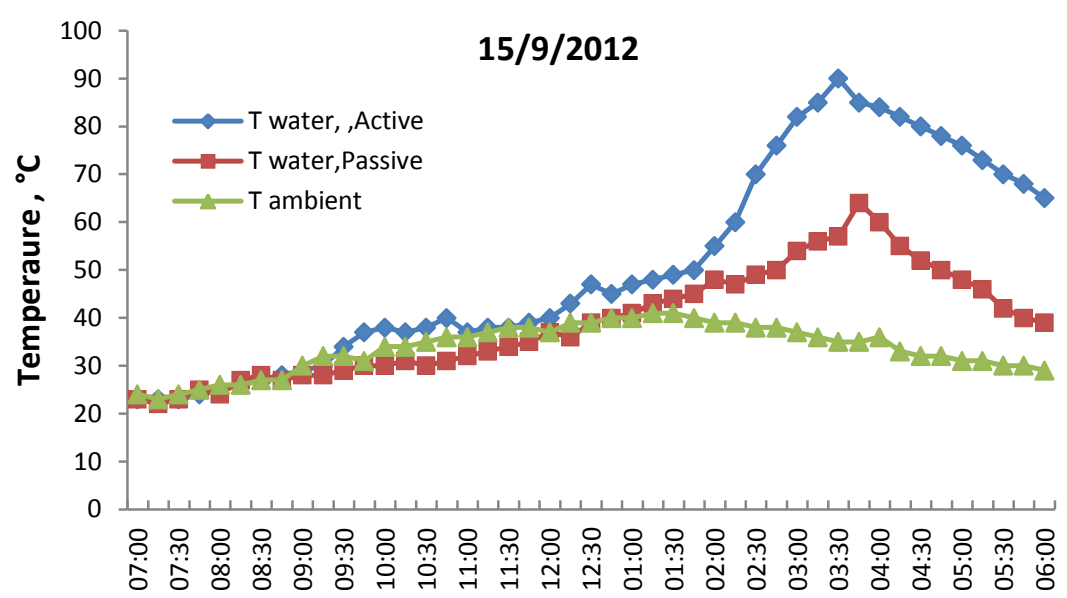

Day, time, hour

Fig. (7). Variations of ambient temperature and basin water temperature for the passive and the active solar stills (15/9/2012)

\subsubsection{Hourly temperature variations of oil cycle}

Figure (8) shows the temperature variation of the oil cycle for the selected days. It is noticed that the temperature of the inlet oil to the heat exchanger has a higher value than the outlet oil temperature from the heat exchanger.

\subsection{Water Productivity}

The typical experimental results of the hourly and accumulated water productivity are shown in Figs. (9-11), respectively, the average measured wind speed was $0.5 \mathrm{~m} / \mathrm{s}$. It is clear that the modified system is an efficient than conventional solar still. 


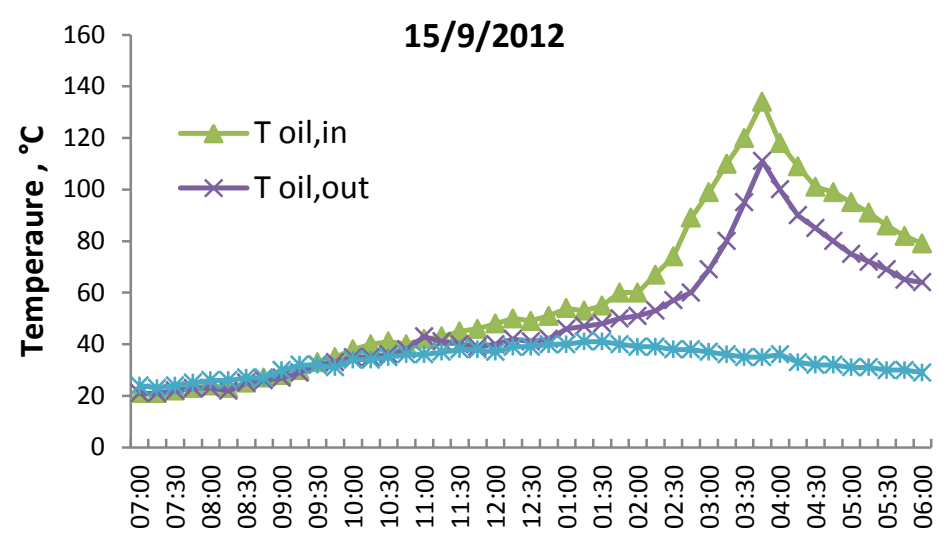

Day time, hour

Fig. (8): Variations of the oil in temperature, the oil out temperature and the ambient temperature (15/9/2012)

\subsubsection{Hourly water productivity}

As shown in Fig (9) there was a considerable increase in the productivity of the active solar still over that of the passive still. It is obvious that the water productivity has a maximum value from (3:00 p.m. to 4:00 p.m.) and then the water productivity decrease. The maximum hourly water productivity on Sep. 15, 2012 was $900 \mathrm{ml} / \mathrm{m}^{2}$ for the active solar still, while it was $640 \mathrm{ml} / \mathrm{m}^{2}$ for the passive solar still at 4:00 p.m.

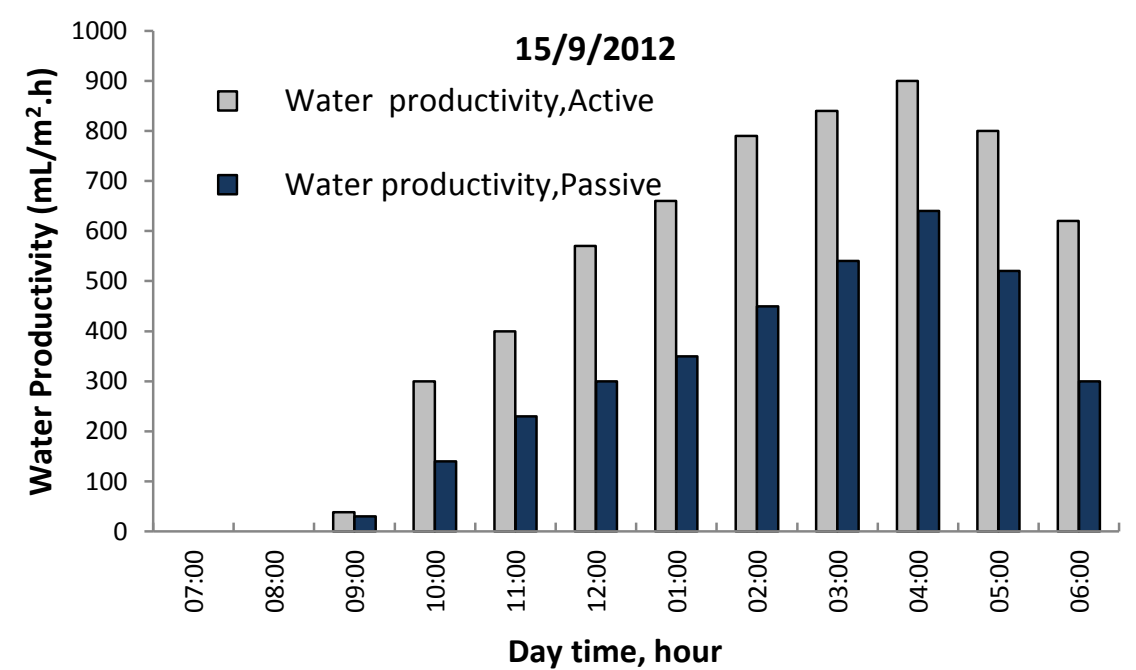

Fig. (9): Fresh water productivity for the passive and the active solar still $(15 / 9 / 2012)$ 


\subsubsection{Accumulative water productivity}

As shown in Fig (10) the accumalative water productivity for active solar still is higher tha the passive solar still, this due to supplying additional heat energy to the basin water from parabolic trough collector to increase its temperature and, of course, increase the temperature difference between the basin water and inner glass temperature which is the main parameter that affects the still productivit. The total water productivity on Sep. 15,2012 was $5918 \mathrm{ml} / \mathrm{m}^{2}$ for the active solar still, while it was 3500 $\mathrm{ml} / \mathrm{m}^{2}$ for the passive solar still.

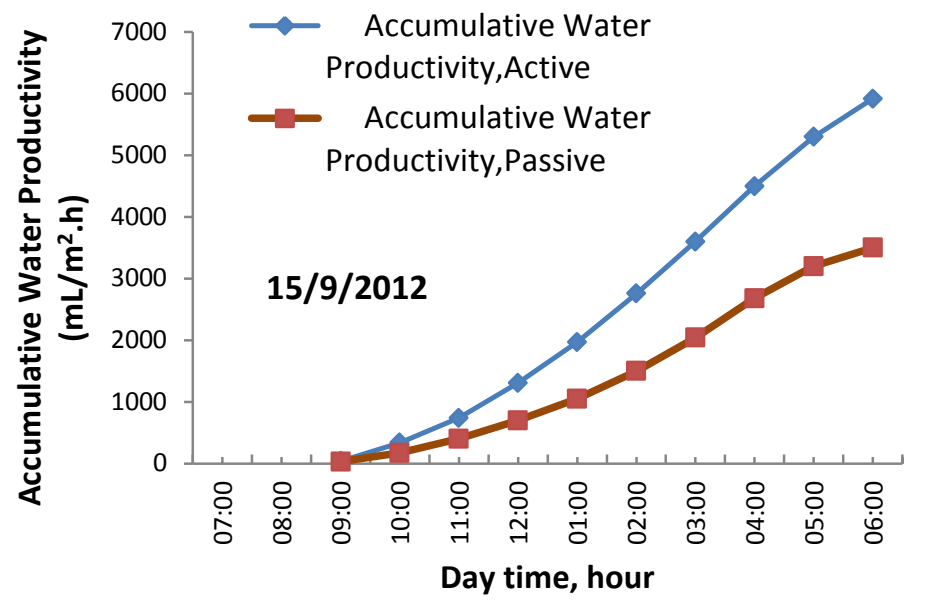

Fig. (10): Accumulative fresh water productivity for the passive and the active solar stills $(15 / 9 / 2012)$

Figure (11) shows the average accumulated water productivity for three months (September, October and November, 2012).

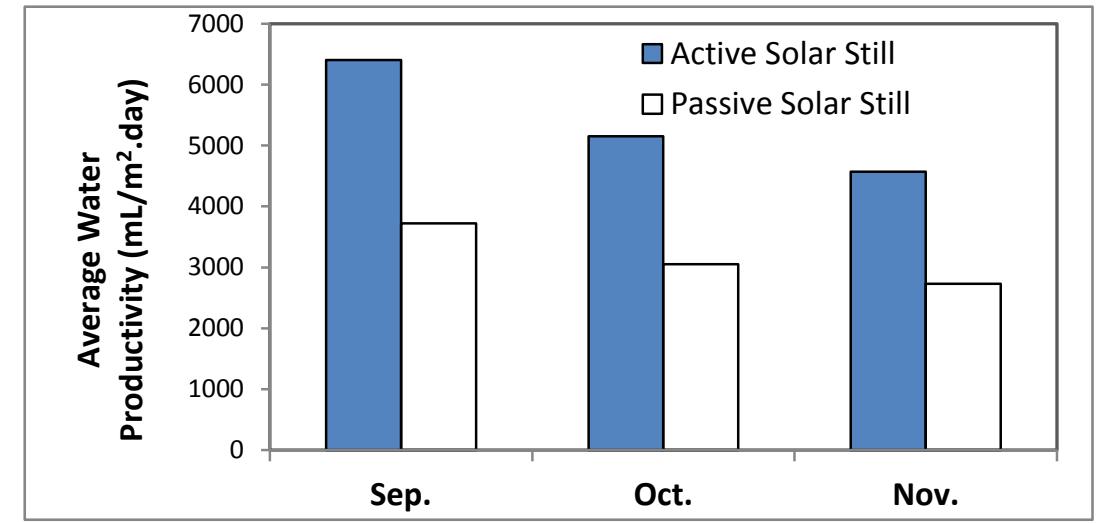

Fig (11): The average accumulated water productivity for the three months 
The average daily production rates of September for the active and passive solar still were $6.403 \mathrm{~L} / \mathrm{m}^{2}$.day and $3.722 \mathrm{~L} / \mathrm{m}^{2}$.day, while in October, they were $5.151 \mathrm{~L} / \mathrm{m}^{2}$.day and $3.052 \mathrm{~L} / \mathrm{m}^{2}$.day and in November they were $4.571 \mathrm{~L} / \mathrm{m}^{2}$.day and $2.728 \mathrm{~L} / \mathrm{m}^{2}$.day.

\section{4- Economic Analysis}

The payback period of the experimental setup depends on the overall manufacture cost, maintenance cost, cost of feed water, operating cost and the required electric power for turning the pump (EInono,2012 and Velmurugan et. al, 2008). So, the economic analysis, according to the current Egyptian conditions, is estimated as the following:

Overall manufacture cost (investment) $=$ EGP 2032

Maintenance cost

Operating cost

$$
\begin{aligned}
& =\text { EGP } 0.6 / \text { day } \\
& =\text { EGP } 0.6 / \text { day }
\end{aligned}
$$

Cost of feed water is negligible. The subsidized price of electricity that given by the government sector is taken as EGP $0.16 \mathrm{kWh}$, then Cost of the required electric power for turning the pump $=(0.0132$ $\mathrm{kWh} /$ day)(0.16 EGP 0.16 kWh) = EGP 0.0021/day

The average productivity of the active solar still of the three months (Sep., Oct. and Nov. $)=5.373$ L/day

The price of distilled water $=$ EGP $2.0 / \mathrm{L}$

The average price of the distilled water production of the active solar still $=(5.373)(2)=$ EGP $10.746 /$ day

Net profit $=$ the price of the produced distilled water - (maintenance cost + operating cost + cost of feed water + cost of the required power for turining the pump)

Net profit $=10.746-(0.6+0.6+0.0+0.0021)=$ EGP $9.54 /$ day

Pay back period $=$ investment $/$ net profit $=2032 / 9.54=213$ days

The payback period should be decreased less than 213 days due to the expected increase in the active still productivity during the summer season.

\section{5- CONCLUSSION}

From the obtained results, it can be concluded with use of modified solar still (active) which gave higher water productivity and lower payback period (213 days) comparing with passive solar still and it should be increase during the summer season. It was also found that the thermal efficiency of the active solar still $(23 \%)$ is lower than the passive solar still $(38 \%)$. 
PROCESS ENGINEERING

\section{REFERENCES}

Abdel-Rehim, Z. S. and A. Lasheen (2007). Experimental and theoretical study of a solar desalination system located in Cairo, Egypt. Desalination; 217: 52-64.

Badran, A. A., A. A. Al-Hallage, I. A. E. Salman and M. Z.Odat (2005). A Solar Still augmented a flat plat colleector. Desalination, 192: 227-234 .

Dunkle, R.V. (1961). The Roof-type still and a Multiple Effect Diffusion still. Solar water distillation. International Heat Transfer Conference. University of Colorado, USA, Part 5: 895-902 .

Elnono, M. (2012). Experimental investigation of a solar still-collector system for solar desalination in rural and desert communities. Misr J. Ag. Eng., 29 (3): 1101-1124.

Rai, G.D. (1980). Solar Energy Utilization, Textbook for Engineering Students. Khanna, Nai Sarak, New Delhi, India.

Sayigh, A.A.M. (1977). Solar energy engineering. 1st Ed., academic press.

Velmurugan, V., S. Kumaran, V. N. Prabhu, and K. Srithar (2008). Productivity engancement of stepped solar still-performance analysis. Thermal Science. 12(3): 153-163.

http://www.fao.org

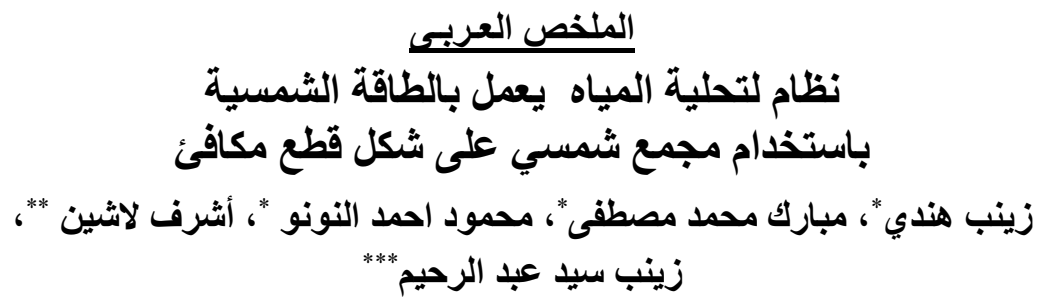

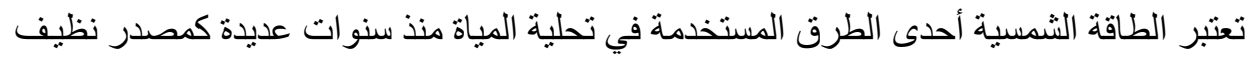

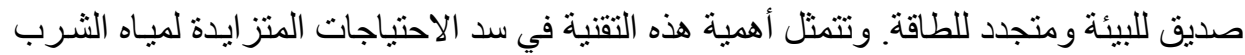

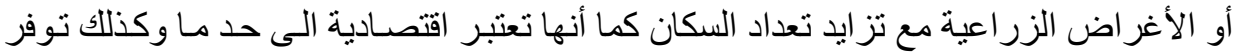

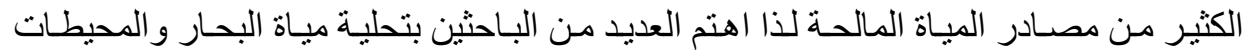
باستخدام الطاقة الثمسية بو اسطة طرق مختلفة ومتعددة.

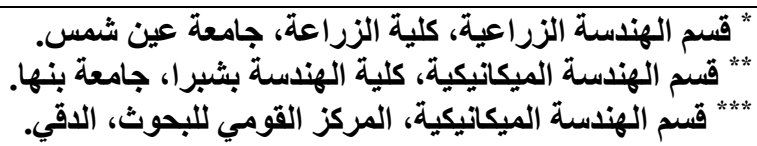




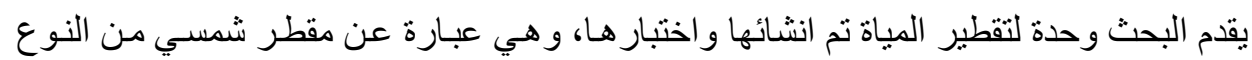

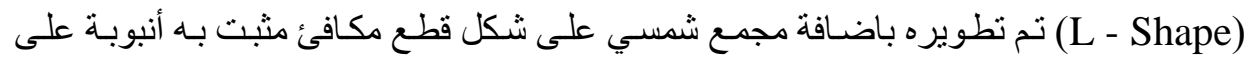

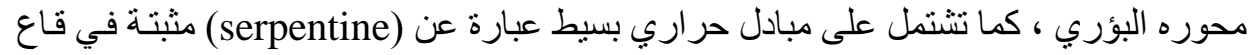

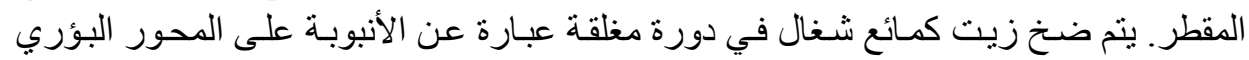

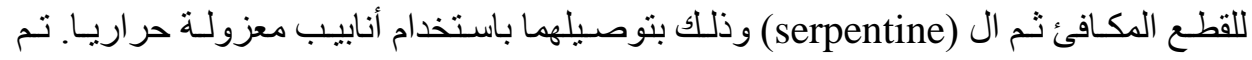

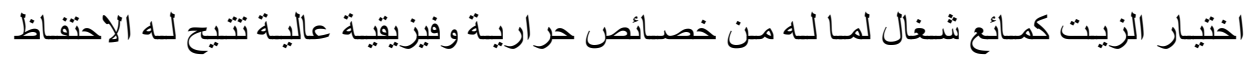

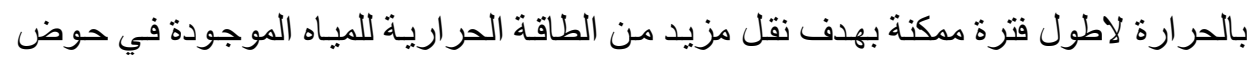

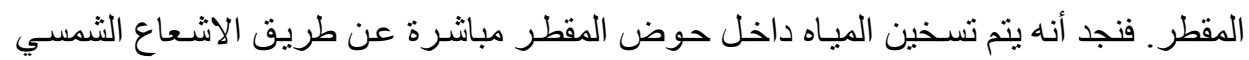

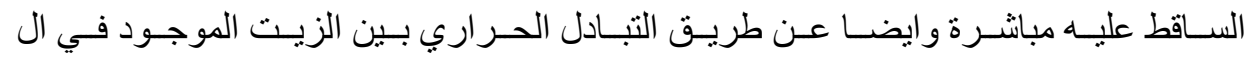

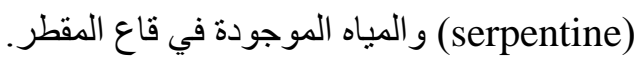

تم عمل دائرة كهربائية للمجمع الثمسي المقتر ح حتى يقوم بعمل تتبع للثمس وذللك حتى يتمكن

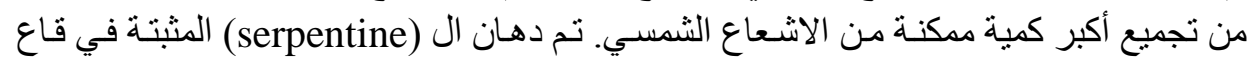
الحوض باللون الاسود وذللك لتقوم بامتصـاص أكبر كمية ممكنة من الطاقة الثمسية. تم تقديم

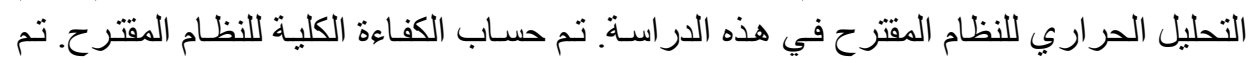

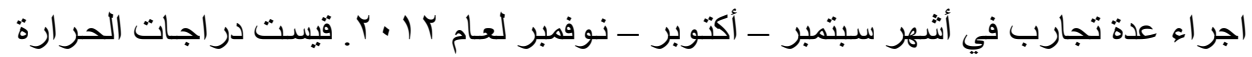

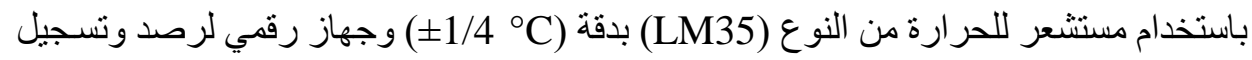

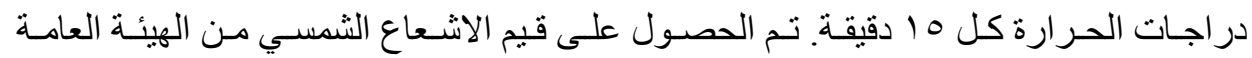
للأرصاد الجوية.

\section{وقد أظهرت النتائج ما يلي: - ماني}

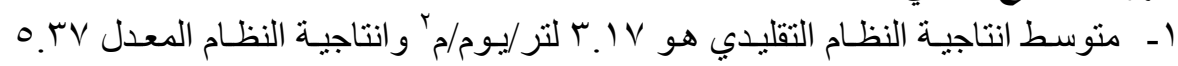

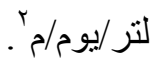

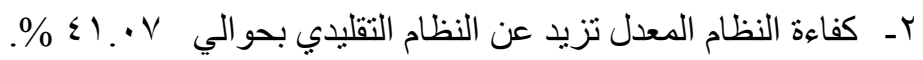

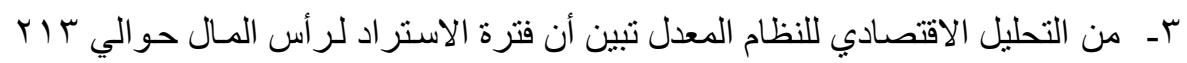

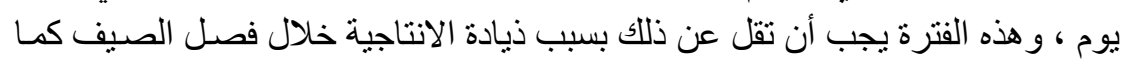

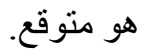

